\title{
The Contextual Effect of Place of Birth Delivery and Biopsychosocial Determinants on Postpartum Depression: A Multilevel Evidence from Yogyakarta
}

\author{
Selvia Febrianti'), Didik Tamtomo²), Uki Retno Budihastuti3) \\ 1)Masters Program in Public Health, Universitas Sebelas Maret \\ 2)Faculty of Medicine, Universitas Sebelas Maret \\ 3)Department of Obstetric and Gynecology, Dr. Moewardi Hospital, Surakarta
}

\section{ABSTRACT}

Background: Postpartum depression is a condition that affects 20\% women in the first four weeks of the puerperium. Postpartum depression can be affected by biological, psychological, sociocultural, and economic factors. This study aimed to analyze biopsychosocial factors affecting postpartum depression in Sleman, Yogyakarta.

Subjects and Method: This was a crosssectional study. This study was conducted at 25 delivery places in Sleman, Yogyakarta, in AugustSeptember 2019. A sample of 200 postpartum mothers was selected by multistage random sampling. The dependent variable was postpartum depression. The independent variables were traditional treatment, age, education, income, parity, pregnancy status, type of delivery, complication, marital satisfaction, and contextual delivery place. The data were collected by questionnaire and analyzed by a multilevel multiple logistic regression.

Results: The risk of postpartum depression increased with delivery with intervention $(b=$ 3.30; $95 \% \mathrm{CI}=1.57$ to $5.02 ; \mathrm{p}<0.001$ ), delivery with complication $(b=3.77 ; 95 \% \mathrm{CI}=2.25$ to 5.28 ; $\mathrm{p}<0.001)$, and age $\geq 35$ years $(\mathrm{b}=0.93 ; 95 \% \mathrm{CI}=-$ 0.20 to $2.07 ; p=0.109$ ). The risk of postpartum depression decreased with traditional treatment $(\mathrm{b}=-1.33 ; 95 \% \mathrm{CI}=-2.51$ to $-0.15 ; \mathrm{p}=0.027)$, education $\geq$ Senior high $\operatorname{school}(\mathrm{b}=-1.98 ; 95 \% \mathrm{CI}=$

-3.59 to $-0.38 ; \mathrm{p}=0.015$ ), family income $\geq \mathrm{Rp}$ $1,701,000(b=-3.55 ; 95 \% \mathrm{CI}=-5.08$ to -2.02 ; $\mathrm{p}<0.001)$, multiparous $(\mathrm{b}=-1.25 ; 95 \% \mathrm{CI}=-2.45$ to $-0.04 ; \mathrm{p}=0.041$ ), intended pregnancy status $(b=-3.11 ; 95 \% C I=-4.96$ to $-1.25 ; p=0.001)$, and happy marital satisfaction $(\mathrm{b}=-1.18 ; 95 \% \mathrm{CI}=-$ 2.30 to -0.05; $\mathrm{p}=0.039)$. There was strong contextual effect of delivery place on postpartum depression with intra-class correlation (ICC)= $31.6 \%$.

Conclusion: The risk of postpartum depression increases with delivery with intervention, delivery with complication, and age $\geq 35$ years. The risk of postpartum depression decreases with traditional treatment, education $\geq$ Senior high school,

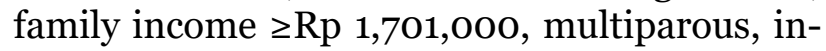
tended pregnancy status, and happy marital satisfaction. There is strong contextual effect of delivery place on postpartum depression.

Keywords: Postpartum depression, determinant, delivery place

\section{Correspondence:}

Selvia Febrianti. Masters Program in Public Health, Universitas Sebelas Maret. Jl. Ir. Sutami 36A, Surakarta 57126, Central Java, Indonesia. Email: selvia.febri11@gmail.com. Mobile: 0811593921

Cite this as:

Febrianti S, Tamtomo D, Budihastuti UR (2020). The Contextual Effect of Place of Birth Delivery and Biopsychosocial Determinants on Postpartum Depression: A Multilevel Evidence from Yogyakarta. J Matern Child Health. 5 (1): 87-98. https://doi.org/10.26911/thejmch.2020.05.01.10

Journal of Maternal and Child Health is licensed under a Creative Commons Attribution-Non Commercial-Share Alike 4.o International License.

\section{BACKGROUND}

The process of psychological adaptation has occurred during pregnancy, before and after delivery. Postpartum depression is a condi- tion that arises immediately after delivering. It is characterized by sadness feeling, loss of interest in daily activities, feeling useless, 
fatigue, and hurting themselves or the babies (Nugroho, 2014). Perinatal depression can increase. It is caused by risk factors such as economic and socio environmental pressures (Gelaye et al., 2016). Mothers who are depressed cannot do their parenting functions properly. Treating post partum mothers with postpartum depression increases the growth and development of new-born. In addition, it reduces the likelihood of diarrhea and malnutrition in children (WHO, 2017).

During pregnancy and puerperium, a mother generally will conduct treatments according to her cultural heritage. These habits are practiced from generation to generation (Mariyati, 2018). Postpartum mothers who use traditional practices show lower rates of postpartum depression than those who do not use traditional practices (Demirel et al., 2018).

In the proportion of delivery place, the majority of delivery assistance was carried out in Independent Practice Midwives (29\%), private hospitals (18\%), and public hospitals (15\%) (Riskesdas, 2018). Some mothers who will give birth feel anxious when they are in the hospital or community health center areas. Anxiety can slow down the contractions, thus slowing down the delivery process. Intervention must be conducted, so that the delivery process run smoothly (Hayati, 2018).

One of the factors found as a risk of postpartum depression was delivery with a tool or intervention, such as; Caesarea section delivery, the use of general anesthesia, kristelle manoeuvre, third or fourth degree perennial tears, and manual intervention that was carried out to discharge the placenta (Martínez et al., 2019). Indonesian people, especially in the Java Island, are very commonly using postpartum treatment with herbal ingredients. There are no studies in Indonesia that publish the effect of traditional treatment on mental health, especially postpartum depression.

\section{SUBJECTS AND METHOD}

\section{Study Design}

This study was an analytic study with cross sectional design. This study was conducted at 25 delivery places in Sleman, Yogyakarta, from August to September 2019.

\section{Population and Sample}

The population of the study was postpartum mothers who were in 2-6 weeks after delivering. The sample of the study was 200 study subjects. The study used multistage random sampling. It was conducted in Sleman Regency, Yogyakarta.

\section{Study Variables}

The dependent variable was postpartum depression. The independent variables were traditional treatment, age, education, income, parity, delivery complication, pregnancy status, marital satisfaction, and contextual delivery place.

\section{Operational Definition of Variables}

Postpartum depression was a psychological adaptation disorder characterized by anxiety, inability to concentrate, self-blame, insomnia, sadness, lack of enthusiasm for life in postpartum mothers 2 to 6 weeks as indicated by the score result of Edinburg Postnatal Depression Scale(EPDS). The measurement scale was continuous and transformed into dichotomous.

Traditional treatment was a treatment by consuming herbs or doing massage in certain parts of the body during the puerperium. The data were collected by questionnaire. The measurement scale was continuous and transformed into dichotomous.

Maternal age was the life span of the mother that was calculated from delivery until filling out the questionnaire. The data were collected by questionnaire. The measurement scale was continuous and transformed into dichotomous. 
Education was a formal education of the study respondents based on their last diplomas ranging from elementary school, junior high school, senior high school, and college level. The data were collected by questionnaire. The measurement scale was categorical.

Income was the amount of income from the head of the family and mother both permanent and additional occupation for one month in Rupiah with the Minimum Wage of Sleman Regency. The data were collected by questionnaire. The measurement scale was continuous and transformed into dichotomous.

Parity was the number of children born to the study subjects. The data were collected by questionnaire. The measurement scale was continuous and transformed into dichotomous.

Type of delivery was the last delivery history of the study subject with normal delivery or delivery with intervention. The data were collected by maternal and child health book. The measurement scale was categorical.

Delivery complication was a health problem faced by the mother during the last delivery process that could interfere or threaten the maternal and baby health. The data were collected by maternal and child health book. The measurement scale was categorical.

Pregnancy status was a condition of pregnancy planned or unintended by the mother outside the expectation of the mother for a reason whose existence was unintended by either party or other party. The data were collected by questionnaire. The measurement scale was categorical.

Marital satisfaction was feeling that was felt by the couple. It depended on the satisfaction level where the marriage was in accordance with the needs and expectations indicated by the value of the Dyad Adjustment Scale (DAS). The measurement scale was continuous and transformed into dichotomous.

\section{Data Analysis}

The univariate data analysis was categorized according to the data scale. The bivariate analysis used the Chi-Square test and the calculation of Odd Ratio (OR) with a 95\% confidence level. Multivariate analysis used a multilevel multiple logistic regression run on Stata 13.

\section{Research Ethic}

Research ethics consisted of informed consent form, anonymity, confidentiality, and ethical clearance. Ethical clearance in this study came from the Health Research Ethics Committee of Dr. Moewardi Hospital, Surakarta, Indonesia. Number: 991/VIII/HREC/2019.

\section{RESULTS}

\section{Sample Characteristics}

The description of the sample of categorical data sample explained the continuous data of each study variable including age, parity, traditional treatment, marital satisfaction, and postpartum depression.

The analysis results of the description of continuous data sample were shown in table 1.

Table 1. Sample characteristics with continuous data

\begin{tabular}{lccccc}
\hline Variable & n & Mean & SD & Min. & Max. \\
\hline Age (year) & 200 & 31.34 & 6.90 & 18 & 45 \\
Parity & 200 & 1.78 & 0.90 & 1 & 5 \\
Traditional treatment & 200 & 6.15 & 1.85 & 4 & 12 \\
Marital satisfaction & 200 & 117.8 & 13.81 & 78 & 146 \\
Postpartum Depression & 200 & 8.58 & 3.49 & 2 & 19 \\
\hline
\end{tabular}


Febrianti S et al./ The Contextual Effect of Place of Birth Delivery

\section{Univariate analysis}

Table 2 shows that there were 95 postpartum mothers (47.5\%) who conducted traditional treatment were and 105 postpartum mothers
(52.5\%) who did not conduct traditional treatment. There were 94 postpartum mothers (47\%) aged <35 years and 106 postpartum mothers (53\%) aged $\geq 35$ years.

Table 2. The description of the study variables with categorical data

\begin{tabular}{|c|c|c|c|}
\hline No & Variable & $\mathbf{n}$ & Percentage \% \\
\hline \multirow[t]{3}{*}{1} & Traditional Treatment & & \\
\hline & Non-traditional treatment (<Mean) & 95 & 47.5 \\
\hline & Traditional treatment ( $\geq$ Mean) & 105 & 52.5 \\
\hline \multirow[t]{3}{*}{2} & Age & & \\
\hline & $<35$ years & 94 & 47 \\
\hline & $\geq 35$ years & 106 & 53 \\
\hline \multirow[t]{3}{*}{3} & Education & & \\
\hline & Low $(<$ SHS $)$ & 165 & 82.5 \\
\hline & $\operatorname{High}(\geq \mathrm{SHS})$ & 35 & 17.5 \\
\hline \multirow[t]{3}{*}{4} & Family Income & & \\
\hline & Inadequate $(<\operatorname{Rp} 1,701,000)$ & 127 & 63.5 \\
\hline & Adequate ( $\geq$ Rp 1,701,000) & 73 & 36.5 \\
\hline \multirow[t]{3}{*}{5} & Parity & & \\
\hline & Primipara $($ child $<2)$ & 96 & 48 \\
\hline & Multipara (child $\geq 2$ ) & 104 & 52 \\
\hline \multirow[t]{3}{*}{6} & Pregnancy Status & & \\
\hline & Intended & 165 & 82.5 \\
\hline & Unintended & 35 & 17.5 \\
\hline \multirow[t]{3}{*}{7} & Type of delivery & & \\
\hline & Normal & 132 & 66 \\
\hline & With intervention & 68 & 34 \\
\hline \multirow[t]{3}{*}{8} & Delivery complication & & \\
\hline & Non-complication & 88 & 44 \\
\hline & Complication & 112 & 56 \\
\hline \multirow[t]{3}{*}{9} & Marital satisfaction & & \\
\hline & Unhappy $(<115)$ & 87 & 43.5 \\
\hline & Happy ( $\geq 115)$ & 113 & 56.5 \\
\hline \multirow[t]{3}{*}{10} & Postpartum Depression & & \\
\hline & Non-depressed $(<10)$ & 116 & 58 \\
\hline & Depressed $(\geq 10)$ & 84 & 42 \\
\hline
\end{tabular}

The number of postpartum mothers with inadequate income $(<\mathrm{Rp} 1,701,000)$ was 127 people (63.5\%) and 73 people (36.5\%) with adequate income ( $\geq \operatorname{Rp} 1,701,000)$.

The number of postpartum mothers with multipara was 104 people (52\%) and 96 people (48\%) with primipara.

The number of postpartum mothers with an intended pregnancy was 165 people (82.5\%) and 35 people (17.5\%) with unintended pregnancy.

The number of postpartum mothers who gave birth with complications was 112 people (56\%) and 88 people (44\%) without complication. Postpartum mothers who gave birth normally was 132 people (66\%) and 68 people (34\%) with intervention.

The number of postpartum mothers who were happy with their marriage was 113 people (56.5\%) and 87 people (43.5\%) who were unhappy with their marriages.

The number of postpartum mothers who did not experience postpartum depression was 116 people (58\%), and 84 people (42\%) who experienced postpartum depression. 
3. The result of bivariate analysis

Table 3 shows that the women who did not conduct traditional treatment had possibility of experiencing depression by 0.46 times ( $\mathrm{OR}=0.46 ; \mathrm{p}=0.001)$. The women aged $\geq 35$ years had possibility of experiencing depression by 1.86 times $(\mathrm{OR}=1.86 ; \mathrm{p}=0.032)$. The women with low education had possibility of experiencing postpartum depression by 0.90 times $(\mathrm{OR}=0.90 ; \mathrm{p}=0.792)$. The women with inadequate income $(<\operatorname{Rp} 1,701,000)$ had possibility of experiencing postpartum depression by 0.13 times $(\geq \operatorname{Rp~1,701,000)}$ $(\mathrm{OR}=0.13 ; \mathrm{p}<0.001)$.

Table 3. The Chi-square test of the effect of traditional treatment and contextual determinant of delivery place on postpartum depression

\begin{tabular}{|c|c|c|c|c|c|c|}
\hline \multirow{2}{*}{ Independent variables } & \multicolumn{2}{|c|}{ Non-depressed } & \multicolumn{2}{|c|}{ Depressed } & \multirow{2}{*}{$\mathbf{O R}$} & \multirow[b]{2}{*}{$\mathbf{p}$} \\
\hline & $n=116$ & $\%$ & $n=84$ & $\%$ & & \\
\hline \multicolumn{7}{|l|}{ Traditional treatment } \\
\hline Non-treatment (< Mean) & 46 & 48.5 & 49 & 51.5 & 0.46 & 0.009 \\
\hline Treatment ( $\geq$ Mean) & 70 & 66.7 & 35 & $33 \cdot 3$ & & \\
\hline \multicolumn{7}{|l|}{ Age } \\
\hline$<35$ years & 62 & $65 \cdot 9$ & 32 & 34.1 & 1.86 & 0.032 \\
\hline$\geq 35$ years & 54 & 50.9 & 52 & 49.1 & & \\
\hline Education & & & & & & \\
\hline Low (<Senior high school) & 95 & 57.6 & 70 & 42.4 & 0.90 & 0.792 \\
\hline High ( $\geq$ Senior high school) & 21 & 60 & 14 & 40 & & \\
\hline \multicolumn{7}{|l|}{ Family income } \\
\hline Inadequate ( $<$ Rp 1,701,000) & 54 & 42.5 & 73 & $57 \cdot 5$ & 0.13 & $<$ \\
\hline Adequate ( $\geq$ Rp 1,701,000) & 62 & 84.9 & 11 & 15.1 & & 0.001 \\
\hline \multicolumn{7}{|l|}{ Parity } \\
\hline Primipara (children < 2) & 50 & 52.1 & 46 & 47.9 & 0.62 & 0.103 \\
\hline Multipara (children $\geq 2$ ) & 66 & 63.5 & 38 & 36.5 & & \\
\hline \multicolumn{7}{|l|}{ Pregnancy status } \\
\hline Unintended & 15 & 42.9 & 20 & 57.1 & 0.47 & 0.046 \\
\hline Intended & 101 & 61.3 & 64 & 38.7 & & \\
\hline \multicolumn{7}{|l|}{ Type of delivery } \\
\hline Normal & 93 & 70.5 & 39 & 29.5 & 4.66 & $<$ \\
\hline With intervention & 23 & 33.8 & 45 & 66.2 & & ד \\
\hline Delivery complication & & & & & & \\
\hline Non-complication & 77 & 87.5 & 11 & 12.5 & 13.10 & $\begin{array}{c}< \\
0.001\end{array}$ \\
\hline $\begin{array}{l}\text { Complication } \\
\text { Marital satisfaction }\end{array}$ & 39 & 34.8 & 73 & 65.2 & & \\
\hline Unhappy $(<115)$ & 41 & 47.2 & 46 & 52.8 & 0.45 & 0.006 \\
\hline Happy ( $\geq 115)$ & 75 & 66.4 & 38 & 33.6 & & \\
\hline
\end{tabular}

\section{The result of multilevel analysis}

Table 4 shows that the postpartum mothers who conducted traditional treatment had logood of experiencing postpartum depression 1.33 units lower than women who did not conducted traditional treatment $(\mathrm{b}=$ -
$1.33 ; 95 \% \mathrm{CI}=-2.51$ to $-0.15 ; \mathrm{p}=0.027)$. There was an effect of age ( $\geq 35$ years) on postpartum depression, but it was statistically nonsignificant $(\mathrm{b}=0.93 ; 95 \% \mathrm{CI}=-0.20$ to 2.07 ; $\mathrm{p}=0.109$ ). Women with education $\geq$ Senior high school had logodd of experiencing post- 
partum depression 1.98 units lower than those with education $<$ Senior high school $(b=$ $-1.98 ; 95 \% \mathrm{CI}=-3.59$ to $-0.38 ; \mathrm{p}=0.015)$.

Postpartum mothers with family income $\geq$ Rp 1,701,00o had logodd of experiencing postpartum depression 3.55 units lower than those with income $<\operatorname{Rp} 1,701,000(b=-$ $3.55 ; 95 \% \mathrm{CI}=-5.08$ to $-2.02 ; \mathrm{p}<0.001$ ).

Multiparous women had logodd of experiencing postpartum depression 1.25 units lower than primiparous $(\mathrm{b}=-1.25 ; 95 \% \mathrm{CI}=-$ 2.45 to $-0.04 ; \mathrm{p}=0.041$ ).

Women with intended pregnancy status had logodd of experiencing postpartum depression 3.77 units lower than those with unintended pregnancy $(\mathrm{b}=-3.11 ; 95 \% \mathrm{CI}=$ 4.96 to -1.25 ; $\mathrm{p}=0.001$ ). Women who delive- red with intervention had logodd of experiencing postpartum depression 3.30 units higher than the women who delivered normally $(b=$ 3.30; 95\% $\mathrm{CI}=1.57$ to $5.02 ; \mathrm{p}<0.001$ ). Women who delivered with complication had logodd of experiencing postpartum depression 3.77 units higher than the women who delivered normally $(\mathrm{b}=3.77 ; 95 \% \mathrm{CI}=2.25$ to 5.28; $\mathrm{p}<0.001$ ).

Women with happy marriage had logodd of experiencing postpartum depression 1.18 units lower than the mothers with unhappy marriage $(\mathrm{b}=-1.18 ; 95 \% \mathrm{CI}=-2.30$ to $-0.05 ; \mathrm{p}=0.039)$. Delivery place had strong contextual effect on postpartum depression with $\mathrm{ICC}=31.6 \%$.

Table 4. The result of multilevel logistic regression analysis of the effect of traditional treatment and contextual determinant of delivery place on postpartum depression

\begin{tabular}{|c|c|c|c|c|}
\hline \multirow{2}{*}{ Independent Variable } & \multirow{2}{*}{$\mathbf{b}$} & \multicolumn{2}{|c|}{ 95\% CI } & \multirow{2}{*}{$\mathbf{p}$} \\
\hline & & Lower Limit & Upper Limit & \\
\hline \multicolumn{5}{|l|}{ Fixed effect } \\
\hline Traditional treatment (Yes) & -1.33 & -2.51 & -0.15 & 0.027 \\
\hline Age $(\geq 35$ years $)$ & 0.93 & -0.20 & 2.07 & 0.109 \\
\hline Education ( $\geq$ SHS) & -1.98 & -3.59 & -0.38 & 0.015 \\
\hline Income ( $\geq \mathrm{Rp} 1,701,00)$ & $-3 \cdot 55$ & -5.08 & -2.02 & $<0.001$ \\
\hline Parity $(\geq 2)$ & -1.25 & -2.45 & -0.04 & 0.041 \\
\hline Pregnancy status (Intended) & -3.11 & -4.96 & -1.25 & 0.001 \\
\hline Complication (Yes) & 3.77 & 2.25 & 5.28 & $<0.001$ \\
\hline Type of delivery (Intervention) & $3 \cdot 30$ & 1.57 & 5.02 & $<0.001$ \\
\hline Marital satisfaction (Happy) & -1.18 & -2.30 & -0.05 & 0.039 \\
\hline \multicolumn{5}{|l|}{ Random effect } \\
\hline \multicolumn{5}{|l|}{ Delivery place } \\
\hline Var (Constant) & 1.52 & 0.31 & 7.28 & \\
\hline $\mathrm{N}=200$ & & & & \\
\hline Log likelihood= -61.18 & & & & \\
\hline LR Test vs linier regression, $\mathrm{p}=0.014$ & & & & \\
\hline Intraclass Correlation $(\mathrm{ICC})=31.6 \%$ & & & & \\
\hline
\end{tabular}

\section{DISCUSSION}

1. The effect of traditional treatment on postpartum depression

The result of the analysis showed that the postpartum mothers who conducted traditional treatment had the lower risk of expe- riencing postpartum depression compared to the mothers who did not conduct traditional treatment.

The postpartum mothers who used traditional practice showed lower rate of postpartum depression compared to those 
who did not use traditional practice (Demirel et al., 2018). Various types of plants were traditionally used for treatment by postpartum mothers (Jamal et al., 2011). Herbal and pilis usually consist of several herbal plants such as; turmeric, meniran, liquorice, lempuyang, temulawak, bangle, and binahong. Pilis is used outside the body (Aziz, 2017). Those plants are important sources of phenolic compounds such as flavonoids which have role as antioxidants (Fitriana et al., 2018). Stagen is used as a reason for culture or hereditary habits. The benefits are good for the body, such as making the body look slim, reducing back pain, and making the body feel comfortable (Rahayu, 2018). Doing massage treatment after delivery is one of the therapies that can be applied in postpartum care because it can increase relaxation, reduce stress, and accelerate hormonal balance after delivery.

The practice of appropriate traditional body massage allows for accelerating the recovery of the puerperium (Aizar, 2018). Providing assistance from families in using various traditional treatments is a form of support that will increase maternal selfconfidence and psychology during puerperium.

\section{The effect of age on postpartum depression}

The result of the study showed that there was an effect of age on postpartum depression, but it was statically non-significant.

At any age, a woman who gave birth is not at risk of experiencing postpartum depression, both at the reproductive and risky age (Wahyuni, 2014). The result of this study is in line with a study that states that maternal age and marital status were not associated with postpartum depression (Pham et al., 2017). Age does not affect the incidence of postpartum depression. However, other researcher argues that there was a significant association between age and the incidence of post- partum depression (Kim, 2018). Giving birth at the risky age is very vulnerable of causing postpartum depression. However, other factors that can affect the incidence of postpartum depression need to be considered, such as pregnancy status, complications during labor, and type of delivery.

\section{The effect of education on post- partum depression}

The result of the study showed that the women with high education had lower risk of experiencing postpartum depression compared to the women with low education.

Education could be associated with the incidence of postpartum depression (Kim, 2018). Education could affect a person's subjective experience and acceptance of depressive symptoms. Therefore, it could postpone the occurrence of symptoms of psychiatric disorder (Pham et al., 2017). Women with low educational status could not think logically and make decisions both emotionally and economically (Gupta et al., 2013). Higher education will encourage a mother to get a lot of information related to problems faced during puerperium. Mothers with higher education usually have prepared everything before pregnancy to delivery (Kurniasari, 2015).

\section{The effect of income on postpartum depression}

The result of this study showed that the postpartum mothers with adequate family

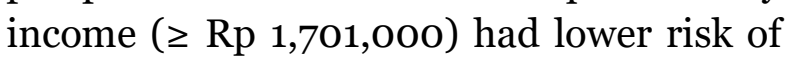
experiencing postpartum depression compared to the postpartum mothers with inadequate income $(<R p 1,701,000)$. Based on the result of a systematic review of a study, one of the risk factors for postpartum depression was financial and socio-environmental pressure (Gelaye et al., 2016). Families who have new family member will be burdened in meeting their daily needs. It could cause stress, thus affecting the behavior of parents. 
As a result, they were difficult to carry out their new roles (Putriarsih, 2017).

Regarding income, it is possible for a woman to work in meeting the family needs. A woman who worked more than 7 hours per day was most likely to have depression during puerperium (Hahnholbrook, 2018). It shows that family income will affect the number of needs of each family member.

\section{The effect of parity on postpartum depression}

The result of the study showed that multiparous women had lower risk of experiencing postpartum depression compared to primiparous women.

Mothers with multiparous status could reduce 2.59 times the incidence of postpartum depression compared to mother with primiparous status (Jannah, 2019). Other causes of depression can arise from a woman who has an unplanned pregnancy, thus burdening herself due to her pregnancy. In addition, the risk factor for postpartum depression was greater (Wijayanti et al, 2013).

\section{The effect of pregnancy status on postpartum depression}

The result of the study showed that there was a negative effect of complication on postpartum depression. The result was statistically significant. The women with intended pregnancy status had lower risk of experiencing postpartum depression compared to the women with unintended pregnancy status. Unintended pregnancy had higher possibility of experiencing postpartum depression by 1.69 units compared to intended pregnancy (Turkcapar et al., 2015).

This study is in line with the result of the study (Ria, 2018). It could be caused by many factors, including pre-pregnancy depression condition, marital status, poverty, and low social support (Abbasi et al., 2013). Psychologically, women who deliver with intended pregnancy status will help and in- crease the confidence to carry out their role as parents.

\section{The effect of type of delivery on postpartum depression}

The result of the study showed that there was a positive effect of type of delivery on postpartum depression. The result was statistically significant. The women who delivered with intervention had higher risk of experiencing postpartum depression compared to the women who delivered normally.

One of the factors found as a risk of postpartum depression was delivery with a tool or intervention, such as; cesarean section delivery, the use of general anesthesia, kristeller maneuver, third or fourth degree perennial tears, and manual intervention that was carried out to discharge the placenta (Martínez et al., 2019).

Postpartum depression occurred in the majority of study subjects who had cesarean section delivery compared to those who delivered by vaginal delivery (Kim, 2018). Section cesarean and cesarean emergency section could increase the risk of postpartum depression (Xu et al., 2017).

On the average, mother who delivered with intervention would feel pain for some time. The pain and discomfort after delivery would inhibit the mother's activities, so that the mother could not take care of herself or her baby optimally.

\section{The effect of delivery complication on postpartum depression}

The result of this study indicated that there was a positive effect of complication on postpartum depression. The result was statistically significant. The women who delivered with complication had higher risk of experiencing postpartum depression compared to the women who delivered normally. Various kinds of complications can occur in the mother during delivery process. A study stated that peripartum hysterectomy, premature birth, solutio placentae, pre-eclampsia, can 
increase the likelihood of postpartum depression (Youn et al., 2017).

Women who had a complication history during delivery were 10.7 times more likely to have postpartum depression (Agarwala et al., 2018). Mothers who experienced premature rupture of membranes had 6 times higher risk and obstructed labor had 5.7 times higher risk of experiencing postpartum depression (Idaiani, 2012). The complication during delivery process will be an experience that will always be remembered and imprinted on a woman's psychic.

\section{The effect of marital satisfaction on postpartum depression}

The result of the study showed that there was a negative effect of the marital satisfaction on postpartum depression. The result was statistically significant. The women who had happy marriage had lower risk of experiencing postpartum depression compared to mothers who had unhappy marriage.

Depressed women reported their poor marital relationship status. This was a strong cause for the incidence of postpartum depression (Kirpinar et al., 2010). In line with the study, the women who had a bad relationship with their spouses had risk of experiencing postpartum depression by 2 times higher than the women who had a good relationship with their spouses (Bhusal, 2018).

Poor quality of marital life was the same as marital dissatisfaction (Nurbaeti et al., 2019). A good relationship with a spouse would inhibit the negative effects that caused stress and increased the sense of life satisfaction after delivery (Gebuza et al., 2016). Having problem with other family members is one of the factors in marital dissatisfaction. Women who lived with their mothers' in-law were more likely to experience depression compared to women who lived only with their husbands (Wang et al., 2017).

10. The contextual effect of delivery place on postpartum depression
The result of the study showed that there was a variety of score in each delivery place. Sleman Regency has 7 public hospitals, 21 private hospitals, 25 community health centers (10 of them are equipped with inpatient facilities), and 74 places of Independent Practice Midwives (Sleman Health Office, 2018). The large number of health facilities make it possible to provide the best services in every health service place. As a result, patients feel comfortable and safe while in the facility.

The diagnosis of depression is often missed in the practice of primary care. One of the reasons was from low screening (Hackley et al., 2010). Women who had negative interaction with health workers and or felt insecure during their labor had higher risk of experiencing postpartum depression (Pham et al., 2017).

\section{AUTHOR CONTRIBUTION}

Selvia Febrianti was the main author who conducted the study, formulated the article of the study, and processed the data. Didik Gunawan played a role in the method and result of the study. Uki Retno Budihastuti played a role in the background and discussion of the study.

\section{CONFLICT OF INTEREST}

There was no conflict of interest.

\section{FUNDING AND SPONSORSHIP}

There was no external funding.

\section{ACKNOWLEDGEMENT}

We give the best gratitude to the Local Government of Sleman Regency for allowing us to conduct this study. We also give the gratitude to all of the postpartum mothers who have been willing and participated to become the respondents of the study.

\section{REFERENCE}

Abbasi S, Chuang CH, Dagher R, Zhu J, Kjerulff K (2013). Unintended pregnancy and postpartum depression 
Febrianti S et al./ The Contextual Effect of Place of Birth Delivery

among first-time mothers, J Women's Health, 22(5); 412-416. doi: 10.1089/jwh.2012.3926.

Agarwala A, Arathi RP, Narayanan P (2018). Prevalence and predictors of postpartum depression among mothers in the rural areas of Udupi Taluk, Karnataka, India: A cross-sectional study', Clinical Clin Epidemiol Glob Health. Elsevier, (August); 3-6. doi: 10.1016/j.cegh.2018.08.009.

Aizar E (2018). Massage postpartum and fungtional status in postpartum mother in medan, Buletin farmatera. 3(1): 2432. Retrieved from: http://jurnal.umsu.ac.id/index.php/buletin_farmate ra

Bhusal BR, Bhandari N (2018). Identifying the factors associated with depressive symptoms among postpartum mothers in Kathmandu, Nepal, International Journal of Nursing Sciences. 5(3): 268274. doi: 10.1016/j.ijnss.2018.04.011.

Demirel G, Egri G, Yesildag B, Doganer A (2018). Effects of traditional practices in the postpartum period on postpartum depression, Health Care for Women International. 39(1);65-78. doi:10.1080/o7399332.2017.137049.

Gelaye B, Rondon M, Araya R, Williams MA (2016). Epidemiology of maternal depression, risk factors, and child outcomes in low-income and middleincome countries, The Lancet Psychiatry. 3(10); 973982. doi: 10.1016/S22150366(16)30284-X.

Dinas Kesehatan Kabupaten Sleman (2018). Profil Kesehatan Kabupaten Sleman Tahun 2018, Sleman. Dinas Kesehatan Kabupaten Sleman. Retrieved from http://dinkes.slemankab.go.id

Fitriana WD, Banun S, Istiqomah T, Ersam $T$, Fatmawati S (2018). The relationship of secondary metabolites: a study of Indonesian traditional herbal medicine
(Jamu) for post-partum maternal care use, AIP Conference Proceedings 2049, 020096, 1-8. Retrieved from https://doi.org/10.1063/1.5082501

Gelaye B, Rondon M, Araya R, Williams MA (2016). Epidemiology of maternal depression, risk factors, and child outcomes in low-income and middle-income countries, Lancet Psychiatry. 3(10): 973-982. https://doi.org/10.1016/S22150366(16)30284X.Epidemiolo gy.

Gebuza G, Kazmierczak M, Malgorzata MM, Banaszkiewicz (2016). Adequacy of social support and satisfaction with life during childbirth, Ann Transplant. 22(2): 135-140. https://doi.org/10.1016/j.poamed.2016.01.004

Gupta S, Kishore J, Mala YM, Ramji S, Aggarwala R (2013). Postpartum depression in North Indian women: Prevalence and risk factors, J Obstet Gynaecol India. 63(4): 223-229. doi: 10.1007/s13224-013-0399-X.

Hackley B, Sharma C, Kedzior A, Sreenivasan $S$ (2010). Managing mental health conditions in primary care settings, $\mathrm{J}$ Midwifery Women's Health. Elsevier Ltd, 55(1): 9-19. doi: 10.1016/j.jmwh.2009.06.004.

Hahn-holbrook J (2018). Economic and health predictors of national postpartum depression prevalence: a systematic review, meta-analysis, and meta-regression of 291 studies from 56 countries, Front psychiatri. 8 (248): 123. doi: 10.3389/fpsyt.2017.00248.

Martínez HA, Rodríguez-Almagro J, MolinaAlarcón M, Infante-Torres N, Donate Manzanares M, Martínez-Galiano JM (2019). Postpartum post-traumatic stress disorder: Associated perinatal factors and quality of life, J Affect Disord. 249; 143-150. doi: 10.1016/j.jad.2019.01.042. 
Idaiani S, Basuki B (2012). Postpartum depression in Indonesia women: a national study, HSJI. 3(6); 3-8. doi: 10.22435/hsji.v3i1Jun.396.3-8.

Jamal JA, Ghafar ZA, Husain K (2011). Medicinal Plants used for postnatal care in malay traditional medicine in the peninsular Malaysia, J Pharmacogn phytochem. 3(24): 15-24. doi: 10.5530/pj.2011.24.4.

Jannah AM, Budihastuti UR, Murti B (2019). Contextual Effect of Place of Birth Delivery on Depression in Karanganyar, Central Java, J Matern Child Health. 4(3): 212-221. doi: 10.26911/thejmch.2019.04.03.08.

Kim Y, Dee V (2018). Sociodemographic and obstetric factors related to symptoms of postpartum depression in hispanic women in rural California, J Obstet Gynecol Neonatal Nurs. 47(1): 23-31. doi: 10.1016/j.jogn.2017.11.012.

Kirpinar I, Gözüm S, Pasinliolu T (2010). Prospective study of postpartum depression in eastern Turkey prevalence, socio-demographic and obstetric correlates, prenatal anxiety and early awareness, J Clin Nurs. 19(3-4): 422-431. doi: 10.1111/j.1365-2702.2009.03046.x. Mariyati, Tumansery GS (2018). Perawatan diri berbasis budaya selama masa nifas pada ibu postpartum, Jurnal Ilmu Keperawatan. 6(1): 47-56. Retrieved from: http://jurnal.unsyiah.ac.id/jik.

Nurbaeti I, Deoisres W, Hengudomsub P (2019). Association between psychosocial factors and postpartum depression in South Jakarta, Indonesia, BMJ Sex reprod health. 20: 72-76. doi: 10$.1016 /$ j.srhc.2019.02.004.

Nugroho T, Nurrezki, Warnaliza D, Wilis (2014). Buku ajar asuhan kebidanan nifas, Nuha Medika, Yogyakarta.

Pham D, Cormick G, Amyx MM, Gibbons L, Doty M, Brown A, Belizán JM (2017).
Factors associated with postpartum depression in women from low socioeconomic level in Argentina: A hierarchical model approach', J Affect Disord. 227(11): 731-738. doi: 10.1016/j.jad.2017.11.091.

Putriarsih R, Budihastuti UR, Murti B (2017). Prevalence and determinants of postpartum depression in Sukoharjo District, Central Java, J Matern Child Health. O3(01): 395-408. doi: 10.26911/thejmch.2017.03.01.02.

Rahayu DT (2018). Pendidikan komunitas tentang pemakaian bengkung pada ibu nifas di desa Keling Kecamatan Kepung Kabupaten Kediri. At-Tamkin, Jurnal Pengabdian kepada Masyarakat. 1 (1); 35-44. Retrieved from: http://ejournal.uniramalang.ac.id/attamkin/

Ria MB, Budihastuti UR, Sudiyanto A (2018). Risk Factors of postpartum depression at Dr. Moewardi Hospital, Surakarta, J Matern Child Health, 3(1): 81-90. doi: https://doi.org/10.26911/thejmch.2018.03.01.08.

Riskesdas (2018), Hasil Utama Riset Kesehatan Dasar Tahun 2018. Kementerian Kesehatan Badan Penelitian dan Pengembangan Kesehatan. Retrieved from: https://www.depkes.go.id

Turkcapar AF, Kadioğlu N, Aslan E, Tunc S, Zayifoğlu M, Mollamahmutoğlu L (2015). Socio-demographic and clinical features of postpartum depression among Turkish women: A prospective study, BMC Pregnancy and Childbirth. 15(1): 1-8. doi: 10.1186/s12884-0150532-1.

Wahyuni (2014). Faktor internal dan eksternal yang mempengaruhi depresi postpartum. Jurnal terpadu ilmu kesehatan, 3(2): 106-214. Retrieved from jurnal.poltekkessolo.ac.id

Wang Y, Wang YJ, Wang H, RuZhang Y, Jian Ma L, Wang M-Z, Yuan S-X (2017). 
Febrianti S et al./ The Contextual Effect of Place of Birth Delivery

Living with parents or with parents-inlaw and postpartum depression: A preliminary investigation in China, $\mathrm{J}$ Affect Disord. 218: 335-338. doi: 10.1016/j.jad.2017.04.052.

Xu H, Ding Y, Ma Y, Xin X, Zhang D (2017) Cesarean section and risk of postpartum depression: A meta-analysis, $\mathrm{J}$
Psychosom Res. 97: 118-126. doi: 10.1016/j.jpsychores.2017.04.016.

Youn HC, Lee S, Han SW, Kim LY, Lee TS, Oh MJ, Cho GJ (2017). Obstetric risk factors for depression during the postpartum period in South Korea: a nationwide study, J Psychosom Res. 102 (6): 15-20. doi: 10.1016/j.jpsychores.2017.09.003. 